CURRENT ATTITUDES TOWARD CORPORAL PUNISHMENT

\title{
CHILDHOOD EXPERIENCES WITH, AND CURRENT ATTITUDES TOWARD, CORPORAL PUNISHMENT
}

\author{
CHRISTINE A. ATEAH \\ University of Manitoba \\ and \\ C. MELANIE PARKIN \\ Acadia University
}

\begin{abstract}
The purpose of the present study was to determine, in a Canadian sample, the extent to which corporal or physical punishment use continues, personal experiences, and current attitudes. Of the 436 participants, $75 \%$ reported receiving physical punishment as children. Approximately $40 \%$ of participants agreed that corporal punishment is necesssary as a means of discipline. Since parental attitude toward physical punishment has been determined to be an important predictor in its use with children, the authors recommend that parent education programming must include information related to its risks.
\end{abstract}

\section{INTRODUCTION}

In Canada, the practice of physical punishment as a strategy to control or correct the behaviour of children has a long history. Section 43 of the Canadian Criminal Code is a modified version of an eighteenth century British law (Lindfield, 1994/95) where physical force (such as physical punishment) by parents, or persons acting in place of parents, is allowed "within reason" for purposes of correction. Physical or corporal punishment has been defined as "the use of physical force with the intention of causing a child to experience pain but not injury for the purposes of correction or control of the child's behaviour" (Straus, 1994, p. 75). Under this definition, the parent's motivation in using physical punishment is to manage the child's behaviour, not to cause injury. However, it is acknowledged that this definition remains prob-lematic because injury cannot always be assessed, for example, in retrospective re-ports, parental reports, and surveys.

In recent years the practice of physical punishment has been questioned as to its effectiveness and, perhaps more importantly, its potential harmfulness. Its use with children has been linked to many negative developmental outcomes, such as aggression (Azrin \& Holz, 1966; Crick \& Dodge, 1996; Parke \& Slaby, 1983; Steinmetz, 1979), anti-social and criminal behaviour (Dodge, Bates, \& Pettit, 1990; Rodgers, Rowe, \& Chengchang, 1994; Straus, Sugarman, \& Giles-Sims, 1997), negative effects on the parent-child relationship (Crockenberg, 1987; Feshbach, 1987; Redd, Morris, \& Martin, 1975; Van Houten, 1983), and negative mental health effects such as depression and alcoholism (Holmes \& Robins, 1988; Turner \& Finkelhor, 1996). In particular, concern has been raised regarding the role that physical punishment plays in 
the emergence of child physical abuse and its related morbidity and mortality (Gil, 1979; Kadushin \& Martin, 1981; Straus, 1994; Wolfe, 1991). According to an incidence study of child maltreatment in Canada (Trocme et al., 2001), 69\% of substantiated physical abuse cases were the result of inappropriate punishment. Very young children are particularly vulnerable to physical injury because they do not have the physical capability to withstand the force that might be associated with physical punishment. Gelles and Straus (1979) determined that children aged 3 to 4 years comprise one of the peak age ranges for violent victimization because parents find verbal control, such as reasoning or ordering, to be ineffective. Since punishment is unlikely to be effective in modifying behaviour that is not under a child's control due to immature development, parental anger and further punishment are likely to occur (Reid, Patterson, \& Loeber, 1982). As the intensity of physical punishment increases, so does the risk of injury to the child. Escalation of "ordinary" corporal punishment to abuse may occur because of the relatively ineffective and temporary effects of meth-ods such as spanking, where the intensity of the punishment must be increased in or-der to obtain the desired behaviour. This increasingly intense response may lead to an injurious level of parental punishment (Parke, 1977).

Despite such findings, the use of physical punishment with children is not uncommon. An estimated $71 \%$ to $75 \%$ of Canadian parents (Durrant, 1994; Durrant, Rose-Krasnor, \& Broberg, 1997) have used physical punishment with their children. Parent factors (such as childhood experience in receiving corporal punishment and attitudes about physical punishment) have been found to be associated with their use of physical punishment.

\section{Personal History of Physical Punishment.}

The intergenerational transmission of parenting practices, or influence of parents' own childhood experiences on their childrearing practices and attitudes, can be purposeful or unintentional (Van Ijzendoorn, 1992). The frequency of physical punishment received by parents in their own upbringing has been found to be a determinant of their approval (Buntain-Ricklefs, Kemper, Bell, \& Babonis, 1994; Durrant, 1994; Ringwalt, Brown, Rosenbloom, Evans, \& Kotch,1989) and actual use of physical punishment (Buntain-Ricklefs et al., 1994; Graziano, Hamblen, \& Plante, 1996; Holden \& Zambarano, 1992; Rodriquez \& Sutherland, 1999; Socolar \& Stein, 1995; Stattin, Janson, Klackenberg-Larsson, \& Magnusson, 1995; Straus, 1990). In addition, the frequency of spankings which parents received as children has been positively correlated with the frequency with which parents spank their own children (Hemenway, Solnick, \& Carter, 1994).

In addition to the frequency of physical punishment, the specific types of discipline experienced in childhood can influence parents' approval of those disciplinary actions, including actions that can be considered abusive in nature (Belsky, 1978, 1980; Herzberger \& Tennen, 1985; Kempe \& Kempe, 1978; Parke \& Collmer, 1975). In a survey of 679 college students regarding their childhood experiences with corporal punishment, $93 \%$ of the students reported that they were spanked as children, $87 \%$ of those spanked agreed that parents should have the right to spank children, and $83 \%$ indicated that they intended to spank their own future children. However, those who reported never having been spanked as children were significantly less accepting of spanking than those who reported having been spanked. The study's authors con- 
cluded that the experience of being spanked as a child is associated with the greater acceptance of this practice (Graziano \& Namaste, 1990).

However, in two Canadian studies (Ateah \& Durrant, 2001; Durrant et al., 1997) although attitude toward physical punishment predicted its use, having experienced it in childhood did not. Therefore, a childhood history of receiving physical punishment does not necessarily translate into a parental use of physical punishment perhaps because of the increasing public awareness of the potential risks of physical punishment use, of alternatives to physical punishment, and of the role of more proximal factors related to child misbehaviour incidents (such as parental anger and the type of behavioural transgression).

\section{Approval of Physical Punishment}

It seems reasonable to assume that a positive or negative attitude toward physical punishment use would affect its utilization. For some childhood transgressions, such as continuing to misbehave after being told to stop or endangering self or others, the parental response of hitting children is a norm, even an expectation (Straus, 1994). According to Wauchope and Straus (1990), corporal punishment is so prevalent, particularly for preschoolers aged 3 to 5 years, that it is difficult to determine the role that approval plays in its use. For example, Straus (1994) concluded that almost all parents hit their four year old children, whether or not they "believe" in corporal punishment.

Other research has clearly demonstrated a positive relationship between the approval and use of physical punishment by parents. Holden and Zambarano (1992), for example, found strong intercorrelations between attitudes, intentions, and practices of physical punishment. Although a positive attitude toward physical punishment does not determine the rate of physical punishment use on its own, it has been found to be a significant predictor (Jackson et al., 1999; Holden, Coleman, \& Schmidt, 1995). Indeed, in two Canadian studies (Ateah \& Durrant, 2001; Durrant et al., 1997), a positive attitude toward physical punishment was found to be the best predictor of its use. Socolar and Stein (1995) also found a strong correlation between the approval and practice of spanking and a weak correlation between anger and the practice of spanking, and suggest that approval may be more important than affect or impulse in explaining parental use of physical punishment.

\section{Purpose}

Since many experts in child development (Gil, 1979; Kadushin \& Martin, 1981; Straus, 1994) have argued that the societal sanctioning and prevalent use of physical punishment are primary causes of child physical abuse, the need to reduce its use in order to decrease rates of abuse has been identified. As discussed, the experience with and attitude toward physical punishment have both been associated with its use. In recent years, the issue of physical punishment use has been questioned and discussed more openly than in previous times; however, few studies have examined Canadians' attitudes toward physical punishment (Durrant, 1993-94; Durrant et al., 1997). It may indeed be that societal values are becoming less supportive toward the acceptance and practice of physical punishment. The purposes of this study, therefore, are: (a) to determine the extent to which physical punishment use continues in Canada, and (b) to examine personal experiences with and current attitudes towards physical punishment. 


\section{METHOD}

\section{Design}

A cross-sectional survey design was used for this study. Data were collected in Spring, 2000 through the completion of questionnaires. Participants were undergraduate students at the Universities of Manitoba and British Columbia, and community members from British Columbia. Permission was secured by the investigator/ author from each province. Professors were asked permission for class time to invite students to participate in a study on physical discipline involving the completion of a questionnaire which was anticipated to take approximately 10 minutes. Potential participants were informed that study participation was voluntary and anonymous. Student participants in British Columbia received one half-credit for filling out a questionnaire and a second half-credit for having a community member (non student) fill out a second questionnaire. In all other respects, collection procedures were similar in both provinces.

\section{Ethical Considerations}

Ethical approval was obtained from Ethics Review Committees at the Universities of Manitoba and British Columbia prior to contacting any departments, professors, or potential participants. The purpose of the study, its relevance, and the expectations of the subjects were explained verbally and in writing to participants. Respondents were informed that they could refuse to answer any question on the questionnaire and could withdraw from the study at any time. However, it is acknowledged that students who were given academic credits for participating may have experienced some pressure to participate. Participants were informed that, by completing and handing in the questionnaire, they were agreeing to take part in the study. Participants were assured that, since no names were requested on the questionnaire, all responses would remain anonymous and confidential. Respondents who desired a copy of the summary of the research report were invited to complete an address form, detach it, and hand it in to the individual who was collecting the questionnaires.

To maintain the anonymity of participants, no names appeared on the questionnaires. Only the researchers and research assistants had access to the original questionnaires. Address forms from respondents who requested a summary of the final research report were kept separate from the questionnaires. No perceived harmful effects of the study were anticipated, although participants were informed that there was a risk that the recall of childhood disciplinary experiences had the potential to cause some discomfort or anxiety. Subjects were informed that, if this did happen, they could access counselling services.

\section{Instrument}

The instrument used for this study was a questionnaire developed by Hyman (Grant, Parkin, Ateah, \& Hyman, 2000) as part of an international, cross-cultural study of college and university students which compared their experiences and attitudes in relation to physical punishment. The 32 -item questionnaire was primarily made up 
of multiple choice questions focusing on demographics and childhood experi-ences with/current attitudes toward physical punishment. Further questions on at-titudes toward physical punishment included responses on a 5 point Likert-type scale. The questionnaire took approximately 10 minutes to complete.

\section{Sample Characteristics}

The final sample consisted of 436 participants, approximately equal numbers from each province. Table 1 summarizes sample characteristics. Approximately two thirds of respondents were aged 21 years or less, and the majority of respondents were female (70\%). Regarding financial background, most respondents $(92.7 \%)$ in-dicated that they were raised in homes that were about the same or better off than most other households. Most respondents $(84.6 \%)$ were raised by both biological parents.

\begin{tabular}{|c|c|c|}
\hline \multicolumn{3}{|c|}{$\begin{array}{c}\text { TABLE } 1 \\
\text { Sample Characteristics of Participants }(N=436)\end{array}$} \\
\hline Characteristic & Frequency & Percent \\
\hline$\overline{\text { Province }}$ & & \\
\hline $\begin{array}{l}\text { Manitoba } \\
\text { British Columbia }\end{array}$ & $\begin{array}{l}217 \\
219\end{array}$ & $\begin{array}{l}49.8 \\
50.2\end{array}$ \\
\hline $\begin{array}{l}\text { Age } \\
\text { Under } 18 \text { years } \\
18 \text { to } 19 \text { years } \\
20 \text { to } 21 \text { years } \\
22 \text { to } 30 \text { years } \\
\text { Over } 30 \text { years } \\
\text { Missing }\end{array}$ & $\begin{array}{r}18 \\
175 \\
86 \\
68 \\
86 \\
3\end{array}$ & $\begin{array}{r}4.2 \\
40.4 \\
19.9 \\
15.7 \\
19.9 \\
.7\end{array}$ \\
\hline $\begin{array}{l}\text { Gender } \\
\text { Male } \\
\text { Female } \\
\text { Missing }\end{array}$ & $\begin{array}{r}132 \\
302 \\
2\end{array}$ & $\begin{array}{r}30.4 \\
69.6 \\
.5\end{array}$ \\
\hline $\begin{array}{l}\text { Childhood Family Home Income Com } \\
\text { Better off } \\
\text { About the same } \\
\text { Worse off }\end{array}$ & $\begin{array}{l}\text { ther Househo } \\
225 \\
179 \\
32\end{array}$ & $\begin{array}{r}51.6 \\
41.1 \\
7.3\end{array}$ \\
\hline $\begin{array}{l}\text { Raised Primarily by } \\
\text { Both biological parents } \\
\text { One biological parent } \\
\text { One biological and one step parent } \\
\text { Other } \\
\text { Missing }\end{array}$ & $\begin{array}{r}368 \\
34 \\
19 \\
14 \\
1\end{array}$ & $\begin{array}{r}84.6 \\
7.8 \\
4.4 \\
3.2 \\
.2\end{array}$ \\
\hline
\end{tabular}

\section{Analysis}

This study is concerned with childhood experiences with and current attitudes toward the use of physical punishment. Respondents' childhood experiences with and level of support for the use of physical punishment were analyzed to determine: (a) the 
relationship between them, and (b) the relationship between them and a number of demographic factors.

\section{RESULTS}

\section{Experience with Receiving Physical Punishment}

Seventy-five percent $(75 \%)$ of the respondents reported having received physical punishment as children (Table 2). Almost $60 \%$ of those respondents who had experienced physical punishment indicated that it had been administered by both parents; the remaining $40 \%$ of respondents were divided fairly equally between those who had received the physical punishment from their mothers and those whose fathers had physically punished them. Over half of those who had received physical punishment as a child recalled first receiving it under 6 years of age, while just over $40 \%$ recalled first receiving physical punishment between the ages of 6 and 10 years. Almost two-thirds of respondents who had received physical punishment recalled receiving the most physical punishment between 6 and 10 years of age.

Of the 327 respondents who indicated that they received physical punishment as children, most $(84 \%)$ reported being spanked, while $63 \%$ reported being slapped on the body, $37 \%$ reported being slapped on the head, $12 \%$ reported receiving shaking, $18 \%$ reported being whipped, and $34 \%$ reported being hit with an object.

\section{Group Differences}

The sample was divided between those respondents who reported receiving physical punishment in childhood and those who did not. The following characteristics did not differ between the two groups: (a) age $(U=15872, p=.16)$; (b) gender $\left(X^{2}\right.$ $=.33, p=.57)$; and (c) family income $(U=15904, p=.10)$.

\section{Attitude toward Physical Punishment}

Respondents were asked to indicate their agreement with a number of statements related to physical punishment use with children, according to a 5 point Likert-type scale (strongly agree, slightly agree, neutral, slightly disagree, strongly disagree). For the purposes of analysis, these categories were collapsed to the categories of agree, neutral, and disagree. Due to correlations between responses to the statements, "Corporal punishment is necessary as a means of discipline," "Corporal punishment at home is justified," and "If you spare the rod you spoil the child" ( $r$ 's ranged from .47 to $.66, p=.000$ in all cases), only the first statement was used in subsequent analyses. Approximately forty percent $(40.4 \%)$ of respondents agreed with the state-ment, "Corporal punishment is necessary as a means of discipline," while $43.8 \%$ disagreed and $15.1 \%$ neither disagreed nor agreed (Table 3 ).

\section{Group Differences}

There were a number of demographic variables for which there were no differences between those individuals who indicated agreement, neutrality, or disagreement with the statement indicating the necessity of using corporal punishment with children. These are: (a) age $\left(X^{2}=7.64, p=.47\right)$; (b) gender $\left(X^{2}=1.02, p=\right.$ $.60)$; and (c) family income $\left(X^{2}=2.63, p=.96\right)$. In addition, parental childhood ex- 


\section{CURRENT ATTITUDES TOWARD CORPORAL PUNISHMENT}

periences of physical punishment did not result in group differences in current attitude toward the use of physical punishment with children $\left(X^{2}=2.29, p=.32\right)$. However, the type of physical punishment received appears to influence support for its use. For example, respondents who reported being spanked, which is generally considered to be a mild form of punishment, were more likely to report a positive attitude toward

TABLE 2

Experience with Receiving Physical Punishment $(N=436)$

\begin{tabular}{|c|c|c|}
\hline- & Frequency & Percen \\
\hline \multicolumn{3}{|c|}{$\overline{\text { Received Physical Punishment as a Child }}$} \\
\hline Yes & 327 & 75.2 \\
\hline No & 108 & 24.8 \\
\hline Missing & 1 & .2 \\
\hline \multicolumn{3}{|c|}{ Who Gave the Physical Punishment $(n=327)$} \\
\hline Mother & 64 & 14.7 \\
\hline Father & 69 & 15.8 \\
\hline Both & 189 & 57.8 \\
\hline Other & 5 & 1.5 \\
\hline \multicolumn{3}{|c|}{ Age Recalled First Receiving Physical Punishment $(n=327)$} \\
\hline Under 6 years & 177 & 54.5 \\
\hline $6-10$ years & 136 & 41.8 \\
\hline $11-15$ years & 11 & 3.4 \\
\hline Over 15 years & 1 & .3 \\
\hline Missing & 2 & .6 \\
\hline \multicolumn{3}{|c|}{ Age Recalled Receiving the Most Physical Punishment $(n=327)$} \\
\hline Under 6 years & 62 & 18.9 \\
\hline $6-10$ years & 215 & 65.7 \\
\hline $11-15$ years & 40 & 12.2 \\
\hline Over 15 years & 3 & .9 \\
\hline Missing & 7 & 2.1 \\
\hline \multicolumn{3}{|c|}{ Received Spanking as Physical Punishment $(n=327)$} \\
\hline Yes & 275 & 84.1 \\
\hline No & 52 & 14.9 \\
\hline \multicolumn{3}{|c|}{ Received Slapping on Body as Physical Punishment $(n=327)$} \\
\hline Yes & 206 & 63.0 \\
\hline No & 121 & 37.0 \\
\hline \multicolumn{3}{|c|}{ Received Slapping on Head as Physical Punishment $(n=327)$} \\
\hline Yes & 120 & 36.6 \\
\hline No & 207 & 63.3 \\
\hline \multicolumn{3}{|c|}{ Received Shaking as Physical Punishment $(n=327)$} \\
\hline Yes & 38 & 11.6 \\
\hline No & 289 & 88.4 \\
\hline \multicolumn{3}{|c|}{ Received Whipping as Physical Punishment $(n=327)$} \\
\hline Yes & 59 & 18.0 \\
\hline No & 268 & 81.9 \\
\hline \multicolumn{3}{|c|}{ Was Hit with an Object as Physical Punishment $(n=327)$} \\
\hline Yes & 112 & 34.3 \\
\hline
\end{tabular}


physical punishment than those who reported receiving one or more of the other forms of physical punishment listed, most of which may be considered as more harsh in nature than spanking $\left(X^{2}=10.10, p=.006\right)$. However, there was no group difference in attitude toward physical punishment among those who had been more harshly disciplined such as those who reported being whipped $\left(X^{2}=1.12, p=.57\right)$.

TABLE 3

Attitude toward Physical Punishment $(N=436)$

\begin{tabular}{lrr}
\hline & Frequency & Percent \\
\hline$\overline{\text { Physical Punishment Is Necessary as a Means of Discipline }}$ \\
Agree & 176 & \\
Neither agree nor disagree & 66 & 40.4 \\
Disagree & 191 & 15.1 \\
Missing & 3 & .7 \\
\hline
\end{tabular}

\section{DISCUSSION}

\section{Experience with Receiving Physical Punishment}

Seventy-five percent (75\%) of respondents in this study reported having received physical punishment as children. These findings are somewhat lower than previous studies on Canadians' experiences with receiving physical punishment in childhood: $88 \%$ of Durrant's (1993-4) respondents and 91\% of Ateah and Durrant's (2001) respondents reported receiving physical punishment as children. This lower percentage may reflect a decreasing trend toward the use of physical punishment in light of increasing public discussion and awareness of the issue.

Regarding the type of physical punishment experienced by those who reported receiving it, the majority reporting being spanked $(84 \%)$ or slapped $(63 \%)$, which is consistent with documentation that identified spanking and slapping as the most common form of physical punishment. The reported frequency of two other forms of physical punishment identified, whipping (18\%) and being hit with an object (34\%), are higher than expected, since these are not usually considered common forms of physical punishment and generally may be more likely than spanking to be considered abusive in nature.

The finding that most respondents recall first receiving physical punishment under the age of six years is convergent with previous research findings. However, the finding that most respondents reported experiencing the most physical punishment between the ages of 6 and 10 years is divergent from previous research, which indi- 
cates that physical punishment is most likely to occur during the preschool years (Jackson et al., 1999; Wauchope \& Straus, 1990). However, memories of preschoolage years may not be as clear as memories of school-age years.

\section{Attitude toward Physical Punishment}

Approximately $40 \%$ of respondents agreed with the statement that "Corporal punishment is necessary as a means of discipline." This finding is convergent with findings by Ateah and Durrant (2001), where $42 \%$ of parents agreed with a similar statement. Durrant et al. (1997) also found that approximately $62 \%$ of respondents disagreed that physical punishment was never necessary which suggests that the remainder were either in agreement with or neutral regarding the necessity of physical punishment of children.

Those respondents who had received milder forms of physical punishment, such as spanking, were more likely to have a positive attitude toward physical punishment than those who reported being physically punished, but not spanked. However, there was no difference in support of physical punishment among those who had reported experiencing more severe forms of physical punishment, such as whipping.

\section{CONCLUSIONS}

Attitude toward physical punishment has been demonstrated in many previous studies to be an important predictor in its use with children. Findings from this study have demonstrated that having received physical punishment as a child does not automatically mean that one will develop a positive attitude toward physical punishment with children. Clearly, there are other factors affecting attitudes toward and/or decisions to use physical punishment with children.

The focus of this study was on personal factors related to use of physical punishment, rather than any situational factors. The fact that over half of the respondents either agreed with $(40.4 \%)$, or were neutral toward $(15.1 \%)$, the statement that physical punishment is necessary clearly indicates that there continues to be substantial support for its use. In addition to personal background, other factors related to physical punishment use which are more situational in nature (such as maternal anger and the type of behavioural transgression) also have been reported to be predictors of physical punishment in other research (Ateah \& Durrant, 2001). Therefore, in order to decrease the use of physical punishment, public education programs ideally should: (a) be multifaceted, (b) include information on the risks of physical punishment, (c) be directed at changing attitudes, and (d) provide content on normal child behaviour and angermanagement strategies.

Parent education intervention strategies directed at altering attitudes toward physical punishment and ultimately decreasing its use require research-based program development and evaluation. In addition, health care professionals (nurses, physicians, social workers, and psychologists) who work with parents need to become aware of the harmful effects of using physical punishment and to urge parents to practice nonphysical disciplinary strategies with their children.

\section{RÉSUMÉ}


Le but de la présente étude devaient déterminer, dans un échantillon canadien, le point auquel utilisation corporelle de punition continue, des expériences personnelles, et les attitudes courantes. Des 436 participants, $75 \%$ a rapporté recevoir la punition physique comme enfants. Approximativement $40 \%$ de participants a convenu que la punition corporelle est nécessaire en tant que des moyens de discipline. Puisque l'attitude parentale envers la punition physique a été déterminée pour être un prédiseur important dans son utilisation avec des enfants, les auteurs recommandent que la programmation d'éducation de parent doit inclure l'information liée à ses risques.

\section{REFERENCES}

Ateah, C.A., \& Durrant, J.E. (2001). Maternal use of physical punishment in response to child misbehaviour: Implications for child abuse prevention. Manuscript submitted for publication.

Azrin, N.H. \& Holz, W.C. (1966). Punishment. In W.K. Honig (Ed.), Operant behavior (pp.390-447). New York: Appleton-Century-Crofts.

Belsky, J. (1978). Three theoretical models of child abuse: A critical review. International Journal of Child Abuse and Neglect, 2, 37-49.

Belsky, J. (1980). Child maltreatment: An ecological integration. American Psychologist, 35, 320-335.

Buntain-Ricklefs, J.J., Kemper, K.J., Bell, M., \& Babonis, T. (1994). Punishments: What predicts adult approval? Child Abuse \& Neglect, 18(11), 945-955.

Crick, N.R., \& Dodge, K.A. (1996). Social information-processing mechanisms in reactive and proactive aggression. Child Development, 67, 993-1002.

Crockenberg, S. (1987). Predictors and correlates of anger toward and punitive control of toddlers by adolescent mothers. Child Development, 58, 964-975.

Dodge, K.A., Bates, J.E., \& Pettit, G.S. (1990). Socialization mediators of the relation between socioeconomic status and child conduct problems. Child Development, 65, 1678-1683.

Durrant, J.E. (1993-94). Sparing the rod: Manitobans' attitudes toward the abolition of physical discipline and implications for policy change. Canada's Mental Health, Winter, 2-6.

Durrant, J.E. (1994). The abolition of corporal punishment in Canada: Parents' versus children's rights. The International Journal of Children's Rights, 2, 129-136.

Durrant, J.E., Rose-Krasnor, L., \& Broberg, A.G. (1997) Maternal beliefs about physical punishment in Sweden and Canada. Manuscript submitted for publication.

Feshbach, N.D. (1987). Parental empathy and child adjustment/maladjustment. In N. Eisenberg \& J. Strayer (Eds.), Empathy and its development (pp. 271-291). New York: Cambridge University Press.

Gil, D.G. (1979). Unraveling child abuse. In D.G. Gil (Ed.), Child abuse and violence (pp. 317). New York: AMS Press.

Grant, T., Parkin, M., Ateah, C., \& Hyman, I. (2000, August). Disciplinary practices in North America: America \& Canada. Paper presented at the $108^{\text {th }}$ Annual Convention of the American Psychological Association, Washington, DC.

Graziano, A.M., Hamblen, J. L., \& Plante, W.A., (1996). Subabusive violence in child rearing in middle-class American families. Pediatrics, 98(4) Supplement, 845-851.

Graziano, A.M. \& Namaste, K.A. (1990). Parental use of physical force in child discipline: A survey of 679 college students. Journal of Interpersonal Violence, 5(4), 449-463.

Hemenway, D., Solnick, S., \& Carter, J. (1994). Child-rearing violence. Child Abuse \& Neglect, 18(12), 1011-1020.

Herzberger, S.D., \& Tennen, H. (1985). The effect of self-relevance on judgments of moderate and severe disciplinary encounters. Journal of Marriage and the Family, 5, 311-318.

Holden, G.W., Coleman, S.M., \& Schmidt, K.L. (1995). Why 3-year old children get spanked: Parent and child determinants as reported by college-educated mothers. Merrill-Palmer 


\section{CURRENT ATTITUDES TOWARD CORPORAL PUNISHMENT}

Quarterly, 41(4), 431-452.

Holden, G.W., \& Zambarano, R.J. (1992). Passing the rod: Similarities between parents and their young children in orientations toward physical punishments. In I.E. Sigel, A.V. McGilliguddy-DeLisi, \& J.J. Goodnow (Eds.), Parental belief systems: The psychological consequences for children (pp. 143-172). Hillsdale, NJ: Lawrence Erlbaum Associates.

Holmes, S.J., \& Robins, L.N. (1988). The role of parental disciplinary practices in the development of depression and alcoholism. Psychiatry, 51, 24-35.

Jackson, S., Thompson, R.A., Christiansen, E.H., Colman, R.A., Wyatt, J., Buckendahl, C.W., Wilcox, B.L., \& Peterson, R. (1999). Predicting abuse-prone parental attitudes and discipline practices in a nationally representative sample. Child Abuse \& Neglect, 23(1), 15-29.

Kadushin, A., \& Martin, J.A. (1981). Child abuse: An interactional event. New York: Colum-bia University Press.

Kempe, R.S., \& Kempe, C.H. (1978). Child abuse. Cambridge, MA: Harvard University Press.

Parke, R.D., \& Collmer, C.W. (1975). Child abuse: An interdisciplinary analysis. In E.M. Hetherington (Ed.), Review of child development research (Volume 5, pp. 509-590). Chicago: University of Chicago Press.

Parke, R.D., \& Slaby, R.G. (1983). The development of aggression. In E.M. Hetherington (Ed.), P.H. Mussen (Series Ed.), Handbook of child psychology, Vol. 4: Socialization, per-sonality, and social development (pp. 547-641). New York: Wiley.

Redd, W.H., Morris, E.K., \& Martin, J.A. (1975). Effects of positive and negative adult-child interactions on children's social preference. Journal of Experimental Child Psychology, 19, 153-164.

Ringwalt, C.L., Brown, D.C., Rosenbloom, L.B., Evans, G.A. \& Kotch, J.B. (1989). Predicting adult approval of corporal punishment from childhood parenting experiences. Journal of Family Violence, 4(4), 339-351.

Rodriquez, C.M., \& Sutherland, D. (1999). Predictors of parents' physical disciplinary practices. Child Abuse \& Neglect, 23(7), 651 - 657.

Rogers, J.L., Rowe, D.C., \& Chengchang, L. (1994). Beyond nature versus nurture: DF analysis of nonshared influences on problem behaviors. Developmental Psychology, 30(3), 374384

Socolar, R.R.S, \& Stein, R.E.K., (1995). Spanking infants and toddlers: Maternal belief and practice. Pediatrics, 95(1), 105-111.

Stattin, J., Janson, H., Klackenberg-Larsson, I., \& Magnusson, D. (1995). Corporal punishment in everyday life: An intergenerational perspective. In J. McCord (Ed.), Coercion and punishment in long-term perspectives (pp. 315-247). Cambridge: Cambridge University Press.

Steinmetz, S.K. (1979). Disciplinary Techniques and their relationship to aggressiveness, dependency, and conscience. In W.R. Burr, R. Hill, F.I. Nye, \& I.L. Reiss (Eds.), Contemporary theories about the family: Research based theories, Volume I (pp. 405-438). New York: The Free Press.

Straus, M.A. (1990). Ordinary violence, child abuse, and wife beating: What do they have in common? In M.A. Straus \& R.J. Gelles (Eds.), Physical violence in American families: Risk factors and adaptations to violence in 8145 families (pp. 403-424). New Brunswick, NJ: Transaction.

Straus, M. (1994). Corporal punishment by parents: Should the use of corporal punishment by parents be considered child abuse? Yes. In M.A. Mason \& E. Gambrill (Eds.), Debating children's lives: Current controversies on children and adolescents (pp. 197-203). Thousand Oaks, CA: Sage.

Straus, M.A., Sugarman, D.B., \& Giles-Sims, J. (1997). Spanking by parents and subsequent antisocial behavior of children. Archives of Pediatric and Adolescent Medicine, 151, 761-767.

Trocme, N., MacLaurin, B., Fallon, B., Daciuk, J., Billingsley, D., Tourigny, M., Mayer, M., Wright, J., Barter, K., Burford, G., Hornick, J., Sullivan, R., \& McKenzie, B. (2001). Canadian incidence study of reported child abuse and neglect: Final report. Ottawa: Minister of Public Works and Government Services Canada.

Turner, H.A., \& Finkelhor, D. (1996). Corporal punishment as a stressor among youth. Journal of Marriage and the Family, 58, 155-166. 


\section{CANADIAN JOURNAL OF COMMUNITY MENTAL HEALTH}

Van Houten, R. (1983). Punishment: From the animal laboratory to the applied setting. In S. Axelrod \& J. Apsche (Eds.), The effects of punishment on human behavior (pp. 13-44). New York: Academic.

Van Ijzendoorn, M.H. (1992). Intergenerational transmission of parenting: A review of studies in nonclinical populations. Developmental Review, 12, 76-99.

Wauchope, B., \& Straus, M.A. (1990). Physical punishment and physical abuse of American children: Incidence rates by age, gender, and occupational class. In M.A. Straus \& R.J. Gelles (Eds.), Physical violence in American families (pp. 133-148). New Brunswick, NJ: Transaction Publishers.

Wolfe, D.A. (1991). Preventing physical and emotional abuse of children. New York: The Guilford Press. 